Impact Factor: 4.845(SJIF) Research Journal Of English (RJOE) Vol-5, Issue-2, 2020

www.rjoe.org.in An International Peer-Reviewed English Journal

ISSN: 2456-2696

Indexed in: International Citation Indexing (ICI), International Scientific Indexing (ISI), Directory of Research Journal Indexing (DRJI) Google Scholar \& Cosmos.

\title{
TEACHING SPEAKING SKILLS THROUGH MOTIVATIONAL STRATEGIES
}

\author{
G. Sanjay, \\ Department of English, Andhra University, Vishakhapatnam \\ Professor T. Narayana, \\ Department of English, Andhra University, Vishakhapatnam
}

\begin{abstract}
:
The present study deals with motivational strategies in teaching speaking. For the purpose of this study, thirty practicing teachers of English were interviewed. Some of those teachers work in polytechnic college's urban area and some at rural colleges. As the instrument of this research, a semi-structured interview was used and it contains nine items. The interviews were recorded, transcribed, analysed and discussed. The first part of the research paper is theoretical. The theoretical part, based on relevant literature, attempts to define the general concept of motivation, motivational strategies in general and motivational strategies used for speaking activities. After that, it deals with the development of the speaking skill and with the problems connected with speaking activites. The second part of the article describes the study. It explains the aim of the study, describes the sample (the participants), the instrument and the procedure. The aim of the study, i. e. research questions are defined, the participants' demographic data outlined, and then the instrument (the interview) and the procedure are described. After that, the results are listed and discussed. The discussion is based on the results and is divided into categories according to specific motivational strategies. In the end, conclusions are drawn on the basis of the results and the discussion.
\end{abstract}

Keywords: motivation, motivational strategies, speaking, interview, English as a second language.

\section{Introduction}

As a teacher of the English language, still at the stage of training the students, researcher understands that how important motivation in the second language classroom really is. In the researcher view the most important factor that influences the learning of a second language. It can even outweigh aptitude. Researcher has been motivating the students 
Impact Factor: 4.845(SJIF) Research Journal Of English (RJOE) Vol-5, Issue-2, 2020

www.rjoe.org.in An International Peer-Reviewed English Journal

ISSN: 2456-2696

Indexed in: International Citation Indexing (ICI), International Scientific Indexing (ISI), Directory of Research Journal Indexing (DRJI) Google Scholar \& Cosmos.

to learn to speak English, but students have the problem of speaking anxiety. This anxiety has slowly diminished through my years of training, but it still persists in a certain amount. For these reasons researcher have chosen the topic of motivational strategies in teaching speaking skills for this research. Through it, researcher hopes to learn how to motivate future learners to participate more in speaking activities. However, there are some limitations to this research. The research is qualitative and there is only one method, a semi-structured interview.

\section{Motivation and motivational strategies Definition of motivation}

With the term 'motivation', Researcher tries to explain why people think and behave in the way they do. Since the existence of the term motivation, scholars have tried to find a definition for it, but it is a complex phenomenon for which no clear-cut definition can be offered. As theorist Dörnyei points out, motivation is a hypothetical and abstract concept. This is probably why so many people are interested in it. If researcher wanted to explain why a person behaves in a certain way, researcher would have to take a lot of factors into account, e. g. the social background, the financial status, idealistic beliefs etc. All these individual differences have to be looked at carefully in order to be able to answer the question why some person behaves as he/she does, and the answer still would not be good enough. In spite of these problems in defining motivation, it can be stated that motivation concerns the direction and magnitude of human behaviour. In other words, motivation is responsible for the choice of a particular action or why people decide to do something, the persistence with this activity or how long people are willing to sustain it, and the effort expended on it or how hard people are going to pursue this activity.

The following is an example of a definition of motivation: "In a general sense, motivation can be defined as the dynamically changing cumulative arousal in a person that initiates, directs, coordinates, amplifies, terminates and evaluates the cognitive and motor processes whereby initial wishes and desires are selected, prioritised, operationalised and (successfully or unsuccessfully) acted out." In the field of motivation, there are a lot of different theories, which can be put into two categories: the first one is motivational psychology, which links behaviour to motives stemming from human mental processes, and the second one is social psychology, which looks at action in the light of a broader social and interpersonal context, as reflected primarily by the individual's attitudes. Both categories should be recognised and integrated into our understanding of the complexity of motivation. Motivation is probably the key concept for understanding the process of language learning and has to be taken into account in every second language classroom. Being an expert in the field does not guarantee success in the second language classroom, because without knowledge about motivation and motivational strategies even the best linguist cannot create a good atmosphere for learning a language. 
Impact Factor: 4.845(SJIF) Research Journal Of English (RJOE) Vol-5, Issue-2, 2020

www.rjoe.org.in An International Peer-Reviewed English Journal

ISSN: 2456-2696

Indexed in: International Citation Indexing (ICI), International Scientific Indexing (ISI), Directory of Research Journal Indexing (DRJI) Google Scholar \& Cosmos.

A distinction has to be made between the teaching of a language and the teaching of other school subjects. Being able to speak a foreign language is not just about knowing facts, like for example with history, it is about having the ability to understand and communicate with a whole other culture. It does not involve just knowing the rules, but also altering your identity. This is why special motivational strategies have to be developed and discussed within the field of second language acquisition.

\section{Demotivation}

Two more terms have to be mentioned here, demotivation and teacher motivation. These two concepts have not been researched to the extent learner motivation has, but they are still vital in understanding the general notion of motivation. Demotivation represents all the specific external forces that lower learner motivation, many of which we are still not aware of. These factors have the power to reduce or even remove the existing motivation, even if it is strong. Researcher can speak about 'demotives', which decrease an action tendency. However, not every type of negative influence should necessarily be labelled as a demotive. The following example could illustrate this point: instead of writing his/her homework, a learner chooses to watch a good movie, which is an attractive alternative action that serves as a powerful distraction (Dörnyei, 2001b:142).

According to Dörnyei (2001b:152, 153), there are nine main demotivating factors in the second language classroom, and those are as follows: the teacher (personality, commitment, competence, teaching method), inadequate college facilities (group is too big or not the right level; frequent change of teachers), reduced self-confidence (experience of failure or lack of success), negative attitude towards the second language, compulsory nature of the second language study, interference of another foreign language being studied, negative attitude towards the second language community, attitudes of group members and the course book. These factors were identified by Dörnyei's research, in which he interviewed fifty particulary demotivated secondary school learners of English and German. He concluded that teachers have a significant responsibility when it comes to demotivation, but that one cannot be sure if the factors mentioned are the causes of lost of interest or just side effects of another demotivating factor. Dörnyei (2001b:155) emphasizes that his research on this matter is just an introduction to future research, because a lot of questions are still open to study and discussion.

\section{Teacher motivation}

The other important aspect to be considered as teacher motivation, which, of course varies from one to the other. Teacher motivation could be explained as the teacher's level of enthusiasm and commitment to the teaching of the subject matter. Dörnyei (2001b) points out four factors that have to be taken into account when discussing teacher motivation: the intrinsic component of teacher motivation, social contextual influences, the temporal 
Impact Factor: 4.845(SJIF) Research Journal Of English (RJOE) Vol-5, Issue-2, 2020

www.rjoe.org.in An International Peer-Reviewed English Journal

ISSN: 2456-2696

Indexed in: International Citation Indexing (ICI), International Scientific Indexing (ISI), Directory of Research Journal Indexing (DRJI) Google Scholar \& Cosmos.

dimension of teacher motivation and negative influences on teacher motivation. Dörnyei (2001b) argues that the intrinsic component of teacher motivation is very important and linked to the other three factors mentioned above. Intrinsic motivation is important for teaching, but also for doing any other job. The intrinsic reward of teaching: "Guiding the intellectual and emotional development of students, whether in urban polytechnic colleges or rural polytechnic college, can be profoundly gratifying for teachers, satisfying their psychological needs and contributing to their growth as individuals." Researcher concludes that work (teaching English as a second language in this case) will be more motivationg if it is meaningful, if it allows autonomy and if it provides feedback.

When discussing social contextual influences, Researcher points out that there are micro- and macro contextual influences on teacher motivation. Macro contextual influences are connected to external factors which come from every layer of the society and teachers are exposed to them every day. Micro contextual influences, on the other hand, are related to the environment in which the teacher works. Some of those factors are the following: the college general climate and the existing college's norms, the class sizes, the college resources and facilities, the definition of the teacher's role by colleagues and authorities, general expectations regarding student potential, the school's leadership and decisionmaking structure, etc. The temporal dimension of teacher motivaton refers to the motivation to be a teacher as a lifelong career. Researcher defines the concept of a contingent path: "a series of tasks where successful achievement is necessary to be guaranteed the opportunity to perform the next task, that is, to continue in the path". In every job, the worker's motivation rises if they are able to move up the career ladder. When there is no ladder, i. e. when the contingent path is closed, the level of motivation to do the job effectively lowers.

Last but not least, negative influences on teacher motivation have to be taken into account. Researcher points out five general demotivating factors: the stressful nature of most teaching jobs, the inhibition of teacher autonomy by institutional constraints such as set curricula, insufficient self-efficacy on most teachers' part due to inappropriate training, content repetitiveness and limited potential for intellectual growth and the inadequate career structure. All of these factors have to be taken into account when discussing motivation as well as demotivation. Judging from the research done on demotivation, it seems that learners tend to blame their teachers for the low level of motivation, when it is obvious that being a teacher is not an easy job. Learners also should follow the instructions, when they motivated it is easy to learn language skills.

\section{Motivational strategies}

In the realm of factors that influence motivation in the second language classroom, motivational strategies also have their place. According to Dörnyei (2001a), motivational strategies are motivational influences that are consciously exerted to achieve some 
Impact Factor: 4.845(SJIF) Research Journal Of English (RJOE) Vol-5, Issue-2, 2020

www.rjoe.org.in An International Peer-Reviewed English Journal

ISSN: 2456-2696

Indexed in: International Citation Indexing (ICI), International Scientific Indexing (ISI), Directory of Research Journal Indexing (DRJI) Google Scholar \& Cosmos.

systematic and enduring positive effect. The notion of motivational strategies is relatively new, since there have been no serious attempts to design specific motivational strategies for the application in the second language classroom until the mid-1990s. Now, however, the spectrum of these kinds of motivational strategies is very broad. Dörnyei (2001b) has therefore created a framework for motivational strategies, which is based on the processoriented model by Dörnyei and Ottó (1998). The key units in this framework are the following: creating the basic motivational conditions, generating student motivation, maintaining and protecting motivation and encouraging positive self-evaluation.

When discussing the creating of the basic motivational conditions in the second language classroom, Dörnyei (2001b) emphasizes three important motivational conditions, and those are as follows: appropriate teacher behaviours and a good relationship with the learners, a pleasant and supportive classroom atmosphere and a cohesive learner group with appropriate group norms. After the basic motivational conditions have been established in the second language classroom, teachers should generate positive learner attitudes towards learning the subject matter. The strategies that can be used to achieve this have been arranged into four groups in process-oriented framework, and they are as follows: enhancing the learners' language-related values and attitudes, increasing the learners' 'goalorientedness', making the curriculum relevant for the learners and creating realistic learner beliefs. After this, we arrive at the stage of maintaining and protecting motivation. Without the maintenance of motivation, teachers face the danger of the initial motivation gradually fading away because of external factors such as attractive distractions and many others. For the purpose of preventing this, Researcher has proposed five particulary relevant areas for the maintenance and protection of initial motivation: setting 'proximal subgoals', improving the quality of the learning experience, increasing the learners' self-confidence, creating learner autonomy and promoting self-motivating learner strategies.

Finally, we come to the last stage, namely encouraging positive self-evaluation. Researcher states that teachers should encourage their learners to take credit for their past accomplishments by attributing them to sufficient ability plus reasonable effort. The three areas of postactional strategies that stresses are the following: promoting attributions to effort rather than ability, providing motivational feedback and increasing learner satisfaction and the questions of rewards and grades. As illustrated above, there are a lot of different motivational strategies concerning different stages, but this research will only focus on some motivational strategies connected with the speaking skill. In the following section, these strategies will be explained. It has to be emphasized here that these strategies have been formulated with the help of Dörnyei's book Motivational Strategies in the Language Classroom. Some of those strategies have been thoroughly explained by Dörnyei, whereas some have only been mentioned. Also, the strategies mentioned by Researcher are general 
Impact Factor: 4.845(SJIF) Research Journal Of English (RJOE) Vol-5, Issue-2, 2020

www.rjoe.org.in An International Peer-Reviewed English Journal

ISSN: 2456-2696

Indexed in: International Citation Indexing (ICI), International Scientific Indexing (ISI), Directory of Research Journal Indexing (DRJI) Google Scholar \& Cosmos.

strategies for the second language classroom; however, in this paper they will be adapted to refer to speaking activities.

\section{Strategy 1: Choosing varied tasks}

This strategy attempts to address the problem of monotony of the speaking activities. Sometimes the level of motivation in speaking activities decreases because the same forms of speaking activities are being repeated over and over again. As Researcher points out, monotony is inversely related to variety. In order to break the monotony of speaking activities, they have to be as varied as possible. According to Dörnyei, four aspects of tasks can be varied: linguistic focus of the tasks, main language skills the tasks activate, channel of communication and organizational format. One aspect has to be ruled out, and that is the main language skill the task activates, since the focus is only on the speaking skill. Researcher gives a list of characteristics which make tasks more motivating, and those could easily be used for making speaking activities more varied.

Firstly, the tasks should be challenging, e. g. activities in which learners have to solve a problem, discover something, overcome an obstacle, find hidden information etc. Secondly, the contact of the task should be interesting to the learners. This can be done by connecting the topic to something the learners like and are interested in. Tasks should also have the novelty element. A detail of a familiar activity could be changed so that the whole activity is different. Furthermore, some tasks could deal with controversial, ambiguous or problematic material to intrigue the learners and stimulate their curiosity. Also, the tasks could also use the fantasy element, e. g. acting out something, making up stories, etc. One should keep in mind that learners like to talk about themselves, so the personal element should also be included. A certain amount of humour should also be present in the tasks in order to make them more interesting. There are many more ideas on how to make the tasks more varied.

\section{Strategy 2: Choosing relevant topics for the learners}

The level of motivation can also be lowered if the learners perceive a certain topic to be dull. If a topic is interesting to the learners, it is more likely that they will participate. In order to make the topics more interesting, the teacher could find out what topics the learners want to learn about and then build them into the curriculum. Researcher mentions some means of how to do gather information from learners: interviews and one-to one chats, group discussion and brainstorming, essay writing assignments, questionnaires with openended questions and questionnaires with sentence-completion items. After the information has been gathered, it can be submitted to further discussion so the teacher can come to an agreement with the learners. 
Impact Factor: 4.845(SJIF) Research Journal Of English (RJOE) Vol-5, Issue-2, 2020

www.rjoe.org.in An International Peer-Reviewed English Journal

ISSN: 2456-2696

Indexed in: International Citation Indexing (ICI), International Scientific Indexing (ISI), Directory of Research Journal Indexing (DRJI) Google Scholar \& Cosmos.

\section{Strategy 3: Giving positive information feedback}

According to researcher, positive information feedback involves positive, descriptive feedback regarding the strengths, achievements, progress and attitudes of the learners. This kind of feedback provides learners with information instead of judgment and it does not compare them to their peers, but rather to their own previous achievements. Researcher points out that teachers should provide their learners with regular information feedback about the progress they are making and about the areas which they should particulary concentrate on. Feedback should be regular, so that the learners are always informed about the progress they are making in certain areas.

\section{Strategy 4: Creating specific rules for speaking activities}

In order to avoid unacceptable behaviour in the classroom and motivate the learners to participate more in speaking activities, the teacher should establish group norms or group rules. These should be discussed with the learners at the beginning of a group's life, and also accepted by the learners. The importance of these group norms should be explained and the learners should have the chance to be involved in the discussion about rules and suggest additional rules. After the rules have been formulated by the group and the teacher, they should be displayed (and also the consequences for violating them). After the group norms have been formulated and agreed upon, the teacher should observe those norms consistently and also train the learners to do the same. In that way, learners can take charge of the classroom atmosphere and cope with those, who do not obey the rules.

\section{Strategy 5: Appropriate error correction}

Appropriate error correction is not only connected to the level of motivation in speaking activities, but also to the level of anxiety in speaking activites. Excessive error correction can indeed provoke anxiety. According to Researcher making mistakes is one if the factors that cause anxiety in the second language classroom. The other factors are social comparison, competition and tests. In order to avoid anxiety in the second lnguage classroom, error correction should occur in an appropriate amount and the learners should also be made aware of the fact that errors and mistakes are a normal part of the language learning process. Modern methodologies suggest that error correction should occur when the message was not conveyed and communication has not been achieved. Still, error correction is inevitable in the second language classroom, and the learners have to be taught that there is no second language learning without making mistakes.

\section{Strategy 6: Preventing the mocking of learners with poor speaking skills}

This strategy is not mentioned by theorist Dörnyei (2001a) in the way that it is mentioned in this research, but it still has relevance. Learners should not be mocked because of their poor speaking skills because it lowers their motivation. The teacher should prevent this from happening by explaining to the learners that second language learning is a process 
Impact Factor: 4.845(SJIF) Research Journal Of English (RJOE) Vol-5, Issue-2, 2020

www.rjoe.org.in An International Peer-Reviewed English Journal

ISSN: 2456-2696

Indexed in: International Citation Indexing (ICI), International Scientific Indexing (ISI), Directory of Research Journal Indexing (DRJI) Google Scholar \& Cosmos.

and that not all learners are at the same stage of this process. If it does happen, the teacher should react. This strategy could be incorporated into the establishment of group norms by creating a rule which would say for example, that making fun of colleagues is not acceptable or forbidden. When a learner is being mocked by his/her peers for making a mistake or being able to solve a task, this can lead to further problems in the classroom.

\section{Strategy 7: Promoting cooperation among learners}

Theories Dörnyei (2001a) points out that a cooperative situation is far better that a competitive one. Learners should be taught to work together as a team and to help each other. When learners work together in order to achieve a certain goal, the level of motivation and the expectancy of success rises and the level of anxiety falls. Similary, a competitive atmosphere, where learners try to be better than others, can have negative effects on motivation. He mentiones some of the features of effective cooperative tasks: learners should work in small groups, they should be relying on each other to be able to complete the task, and they should be given some advance training of groups skill and reflect on the cooperative work.

\section{Strategy 8: Dealing with anxious learners}

Sometimes teachers are faced with the problem of certain learners not being willing to participate in speaking activities because of their high level of anxiety. Some of the ways of decreasing anxiety have already been mentioned as part of other strategies, namely avoiding excessive error correction and creating a cooperative atmosphere. This issue can be resolved by providing sufficient advance information about the test, including clear specifications of the criteria that will be used when grading. There should also be enough time to complete the test and a certain amount of self-evaluation and possibly peerevaluation should be used when giving the final grade.

\section{Strategy 9: Promoting contact with native speakers}

This strategy has been mentioned by Dörnyei (2001a) as a part of promoting the learners' awareness of the instrumental values associated with the knowledge of a second language. The level of motivation can be increased if the learners have contact with native speakers and have the opportunity to use their speaking skills this way. Sometimes it is hard to bring a real native speaker to class, but there are other forms of contact with native speakers, e. g. through the internet. If contact with a native speaker cannot be arranged, the teacher should use some kind of substitution. In some cases, these substitutions involve the development of another skill, such as writing; e. g. learners could have pen pals who are native speakers. Modern technology makes this possible.

\section{Literary reviews:}

Sengkey, V. (2018) Student Attitudes and Motivation in Learning English. Human Behavior, Development and Society. 
Impact Factor: 4.845(SJIF) Research Journal Of English (RJOE) Vol-5, Issue-2, 2020

www.rjoe.org.in An International Peer-Reviewed English Journal

ISSN: 2456-2696

Indexed in: International Citation Indexing (ICI), International Scientific Indexing (ISI), Directory of Research Journal Indexing (DRJI) Google Scholar \& Cosmos.

Shams, M. (2008). Students' attitudes, motivation and anxiety towards English language learning. Journal of Research.

Wu, X. (2003). Intrinsic Motivation and Young Language Learners: the Impact of the Classroom Environment.

\section{Research problem:}

In the world of teaching English as a foreign language (and teaching foreign languages in general) it is an accepted fact that the final goal of the process of teaching and learning a language is communication. The final outcome of this process is the students' ability to communicate in the target language. To achieve this goal, the speaking skill has to be developed adequately. Although the other skills are just as important as speaking, without a developed speaking skill no oral communication could exist. The speaking skill is a productive skill and it takes the longest to develop. It is connected to all the other skills and also used for developing them.

There are also some other problems which are somewhat inherent to teaching a foreign language. These are all problems which teachers of English are not only aware of, but have to face them every day. Firstly, a classroom is not a natural environment for learning a foreign language. The best way of learning to speak English (i. e. developing the speaking skill) is learning it outside the classroom. Going to live in America, the UK or any other English speaking country would be far more effective than learning English in an artificial environment such as a classroom. Secondly, teaching English as a school subject is extremely hard because of the size of the groups one has to teach. Realistically, most of the classrooms in our country have about thirty students each.

\section{Aim of the study}

The aim of this diploma paper is to explore practicing English teacher's personal experience in the use of motivational strategies in speaking activities.

These are the research questions:

1. Which motivatonal strategies do teachers of English use in their classrooms?

2. How do these strategies work? How are they being applied? Is the application of the motivational strategies successful?

3. Are there any difficulties in applying the motivational strategies? If so, what are the obstacles in applying the adequate motivational strategy?

\section{Research methodology:}

Polytechnic students are not able to speak fluently and efficiently, to speak efficiently, they need training as well as motivation. Motivation plays important role in learning and teaching speaking skills. Every teacher was asked (per email, cell phone or 
Impact Factor: 4.845(SJIF) Research Journal Of English (RJOE) Vol-5, Issue-2, 2020

www.rjoe.org.in An International Peer-Reviewed English Journal

ISSN: 2456-2696

Indexed in: International Citation Indexing (ICI), International Scientific Indexing (ISI), Directory of Research Journal Indexing (DRJI) Google Scholar \& Cosmos.

personally) to participate in the research. The research topic was explained to the participants by the researcher in advance. This was done to relieve the participants of any possible anxiety and to make them aware that this was not a test of their teaching abilities and that they would not be evaluated. Beside the research topic, the research procedure was also explained to the participants in advance. The participants were also offered to read the research report. The interviews were recorded on a cell phone, copied into the personal computer, listened to and transcribed. As already mentioned, three of the interviews were done by email.

After the interviews were transcribed, the answers were analysed and categorised. Frequently occurring answers were identified and counted. Also, some specific answers from individual teachers were extracted because they might provide interesting and relevant information. After the completion of the list of frequent and individual answers, all the information gathered was reinspected and compared to the literature. It must be noted that frequency of answers was not the only criterion important in this research, because it was assumed that teachers could not say everything in the ten minutes of the interview. For example, it was assumed that the fact that a teacher did not list role-play as a kind of activity she uses could not be taken as an indication that she does not use it at all.

For the purpose of this research, thirty practicing teachers of English were interviewed. They are all female, but different in terms of age, the type of colleges they work in, the geographical region they live in and the number of years of experience. The issues in primarily are connected to the early stages of development of the speaking skill and are somewhat specific. Also, when it comes to polytechnic colleges, a difference has to be made between different types of technical college, because different types of colleges put a different amount of emphasis on learning second languages. There are differences in the level of importance a certain school places on a college subject like English. Two participants are professors of English at a university Department of English language and literature; nine participants are teachers at 10 different colleges.

\section{Instrument}

The main research method used in the present research is a semi-structured interview. The questions for the interview were designed by the researcher, on the basis of Dörnyei's book Motivational Strategies in the Language Classroom (2001), which contains different kinds of motivational strategies, including those referring (directly or indirectly) to speaking activities (see 2. 4.). As speaking is an integral part of almost every lesson of English, different strategies that Dörnyei (2001a) lists can relate to speaking activites. The interview contains nine items, i. e. open-ended questions with the possibility of adding personalized sub questions. This method was chosen in order to get a truthful and individualized response from the participants. Although the interview was designed as an 
Impact Factor: 4.845(SJIF) Research Journal Of English (RJOE) Vol-5, Issue-2, 2020

www.rjoe.org.in An International Peer-Reviewed English Journal

ISSN: 2456-2696

Indexed in: International Citation Indexing (ICI), International Scientific Indexing (ISI), Directory of Research Journal Indexing (DRJI) Google Scholar \& Cosmos.

oral interview, three of the fifteen interviews were done by means of email, because the teachers expressed their wish to answer the question this way.

\section{Conclusion}

There are a number of ways of motivating students to participate more in speaking activities. A lot of these strategies are used by the participants in a positive way, but there are also a few restrictions in our college system. For example, the teachers mostly stick to the topics from the course book because they have to follow the curriculum. Also, more native speakers would come to our colleges if the government helped. Two more restrictions teacher are faced with are the rigid seating arrangements and the sizes of the groups. Some of the strategies are not used in the way researcher explains them, which does not mean that teachers failed in that sense. For example, Dörnyei says that rules should be cleary defined, discussed with the teacher and displayed in the classroom, so that they can always be pointed to. There should also be some sort of punishment for those who do not obey them (including the teacher). This strategy is not used by the majority of the participants, but they still recognize and react to unacceptable behaviour.

In some cases, there is no need to use a certain strategy. Strategies are used differently by every teacher in their learner groups, so that it is difficult to talk about strategies that apply to every single classroom. Of course, there is a lot of potential behind these strategies, and they indeed may help to generate more participation in speaking activities, but they have to be thought through by every teacher for his/her specific classroom. Not only is every learner group different, but every learner is different, and this has to be taken into account when choosing and modifying strategies. Also, every generation is different when compared to the previous one, and as such deserves a different approach. Every participant of this research is aware of that. The teachers are open to suggestions and they know that they can always learn something new. The following is a quote that illustrates how complex and inconstant motivation is. The real problem with motivation, of course, is that everyone is looking for a single and simple answer. Teachers search for one pedagogy that, when exercised, will make all students want to do their homework, come in for after-school help, and score well on their tests and report cards.

Unfortunatey, and realistically, motivating students yesterday, today and tomorrow will never be a singular process." .In spite of the fact that the motivational strategies analysed in this research work differently in different environments, they are still very good strategies worth trying out. They can be modified to suit a specific learner group, but in order to do that, a teacher has to know the learner group very well. In conclusion, one could say that the teachers should be given more freedom and autonomy to adjust their second language courses. The majority of the teachers are not satisfied with the way the school system works, and would be glad if some of the restrictions were to be removed. For them, 
Impact Factor: 4.845(SJIF) Research Journal Of English (RJOE) Vol-5, Issue-2, 2020

www.rjoe.org.in An International Peer-Reviewed English Journal

ISSN: 2456-2696

Indexed in: International Citation Indexing (ICI), International Scientific Indexing (ISI), Directory of Research Journal Indexing (DRJI) Google Scholar \& Cosmos.

this would result in better conditions in the second language classroom and more motivational strategies (for the speaking skill and for other skills as well) could be used. For example, if there were more time and if the groups were smaller, more learners could be approached individually and the level of motivation could be heightened. All the teachers interviewed in this research have a broad knowledge about all kinds of motivational strategies, but they sometimes simply do not have the means to carry them out. Finally, the analysis of the data received in this study has provided us with some insight which could be taken into consideration by future teachers of English, as well as practicing teachers of English as a foreign language. The following is a brief compilation of suggestions for the English language classroom, i. e. motivational strategies for speaking activities:

- Speaking activities should be varied;

- Pair work and role-play are better than group work for speaking activities, because that way, each learner has to speak;

- Learners learn better if the aim of the activity is explained to them;

- Speaking activities should be an integral part of every lesson;

- The topics for speaking activities should reflect the learners' age, interests and personal lives;

- The teacher should get familiar with the learners' interests to be able to choose the topics accordingly

- The feedback about the learners' speaking skill should be informal (objective information on the speaking skill), both positive and negative;

- Rules for speaking activities should be clearly defined, especially at an early age;

- Rules of conduct in the language classroom should be clearly defined, as well as consequences for violating them, which are then reflected upon speaking activities;

- Learners speak in English more when they are given a chance to rehearse what they are going to say;

- Learners have to be made aware that language learning is a process where each learner is at a different stage and mocking learners with a poorer speaking skill is not allowed;

- Error correction should be appropriate and in correlation with the aim of the activity;

- The learners should generally have a cooperative relationship, although some sorts of competition can have a positive effect on motivation;

- Learners with a higher level of anxiety should be consistently and gradually helped by the teacher, both individually and in class;

- Contact with native speakers of English is invaluable in the development of the speaking skill, and when no real contact can be achieved (in form of speaking), a substitution can be used (modern technology). Finally, researcher must add a personal note. Since researcher has started teaching English in the meantime, researcher had an opportunity to check if the guidelines are effective in the practice. Researcher has found that these strategies are indeed 
Impact Factor: 4.845(SJIF) Research Journal Of English (RJOE) Vol-5, Issue-2, 2020

www.rjoe.org.in An International Peer-Reviewed English Journal

ISSN: 2456-2696

Indexed in: International Citation Indexing (ICI), International Scientific Indexing (ISI), Directory of Research Journal Indexing (DRJI) Google Scholar \& Cosmos.

very useful and can be applied successfully. However, researcher have also learned that success should not be expected immediately and that consistency is very important in the application of motivational strategies for speaking as well as other activities.

\section{References:}

- Asmari, A. A. \& Javid, C. Z. (2011). Motivational constructs: A cross sectional Study of EFL students at Taif University. Journal of Social Sciences \& Humanities, XIX(2), 73-104.

- Coskun, L. (2014). Investigation the essential factors on student's motivation through comparing boys and girls in terms of instrumental \& integrative motivation in EFL classrooms. Journal of Educational Social Research, 4(2), 150- 156.

- Demir, B. (2003). The Influence of Various Motivational Factors in Foreign Language Learning. Retrieved October 12th, 2004 from:http://www.ed.gov/databases/ERIC_Digest/.

- Feng, R. \& Chen, H. (2009). An Analysis on the Importance of Motivation and Strategy in Postgraduates English Acquisition. English Language Teaching, 2(3), 93-97.

- Fontecha, A. F. \& Gallego, M. T. (2012). The role of motivation and age in vocabulary knowledge. International Journal of Applied Linguistics, 9, 39-62.

- Harmer, J. (2001) The Practice of English Language Teaching. London: Longman Group Ltd.

- Richards, Jack C. (2008) Teaching Listening and Speaking. Cambridge: Cambridge University Press.

- Shams, M. (2008). Students' attitudes, motivation and anxiety towards English language Ziahosseini, M., \& Salehi, M. (2008). An Investigation of the Relationship between Motivation and Language Learning Strategies. Pazhuhesh-e Zabanha-ye Khareji, 41, 85-107. 